\title{
Pengaruh Keadilan Prosedural Partisipatif dan Internal Locus Of Control Terhadap Kepuasan Kerja Karyawan: Studi Empiris pada Industri Tekstil Sandang dan Kulit di Kabupaten Majalengka
}

\author{
Haris Fauzi \\ Fakultas Ekonomika dan Bisnis Universitas Majalengka, Indonesia \\ Email corresponding author: harisfauzi312@gmail.com
}

\begin{abstract}
ABSTRAK
Penelitian ini bertujuan untuk mengetahui keadilan prosedural partisipatif, internal locus of control dan kepuasan kerja karyawan pada industri tekstil sandang dan kulit di Kabupaten Majalengka. Selain itu, tujuan penelitian ini adalah untuk mengetahui seberapa besar pengaruh keadilan prosedural partisipatif dan internal locus of control terhadap kepuasan kerja karyawan baik secara parsial maupun simultan. Metode penelitian yang digunakan dalam penelitian ini adalah analisis deskriptif dan analisis verifikatif. Hipotesis yang diuji sebanyak tiga hipotesis dengan data yang dikumpulkan dari 116 responden yang dijadikan sebagai sampel. Responden berasal dari karyawan industri tekstil sandang dan kulit yang tergabung dalam Federasi Serikat Pekerja Tekstil Sandang dan Kulit Konfederasi Serikat Pekerja Seluruh Indonesia Kabupaten Majalengka. Uji instrumen dalam penelitian ini adalah validitas dan reliabilitas. Alat analisis yang digunakan adalah uji asumsi klasik, analisis regresi linier berganda, koefisien determinasi, dan uji hipotesis. Untuk uji secara parsial menggunakan uji t dan untuk uji secara simultan menggunakan uji F. Hasil penelitian menunjukkan bahwa keadilan prosedural partisipatif termasuk kategori tinggi, internal locus of control termasuk kategori baik dan kepuasan kerja karyawan termasuk kategori tinggi. Keadilan prosedural partisipatif berpengaruh positif dan signifikan terhadap kepuasan kerja karyawan, internal locus of control berpengaruh positif dan signifikan terhadap kepuasan kerja karyawan, serta secara simultan keadilan prosedural partisipatif dan internal locus of control berpengaruh positif dan signifikan terhadap kepuasan kerja karyawan.
\end{abstract}

Kata Kunci: Keadilan prosedural partisipatif, internal locus of control dan kepuasan kerja karyawan.

\section{PENDAHULUAN}

Pada masa kini, secara universal organisasi selalu menghadapi suatu kondisi yang tidak statis. Perkembangan organisasi merupakan bagian yang tidak terhindarkan dari kehidupan global yang semakin dinamis. Setiap organisasi dituntut untuk beradaptasi dengan perubahan lingkungan yang kompetitif melalui transformasi organisasi. Untuk mewujudkan dinamika keberhasilan suatu organisasi, maka sumber daya manusia perlu diatur secara efektif dan efisien. Menurut Edi Sutrisno ${ }^{6}$ (2016), sumber daya manusia merupakan satu-satunya sumber daya yang memiliki akan perasaan, keinginan, keterampilan, pengetahuan, dorongan, daya, dan karya (rasio, rasa, dan karsa). Semua potensi SDM tersebut berpengaruh terhadap upaya organisasi dalam mencapai tujuan. Manusia selalu berperan aktif dan dominan 
dalam setiap kegiatan organisasi karena manusia menjadi perencana, pelaku, dan penentu terwujudnya organisasi.

Selain kemakmuran, organisasi juga akan menghadapi berbagai problematika yang berimplikasi pada kesenjangan-kesenjangan. Salah satu contoh organisasi yang saat ini banyak dibicarakan oleh khalayak umum adalah organisasi serikat pekerja. Sekarang ini banyak terjadi demonstrasi yang dilakukan oleh para buruh untuk menuntut keadilan-keadilan yang dirasa belum terlaksana. Salah satu contoh aksi unjuk rasa yang terjadi belakangan ini adalah massa buruh Semarang pada tanggal 11 Oktober 2018. Mereka menolak Peraturan Pemerintah Nomor 78 terkait aturan ketenagakerjaan. Menurut mereka, Peraturan Pemerintah tersebut tidak sesuai dengan kebutuhan hidup sehingga para buruh menuntut kenaikan upah sebesar 30 persen (Liputan 6, 2018). Masalah tentang UMK (Upah Minimum Kerja) juga terjadi di Majalengka. Berdasarkan penyusunan UMK, tahun 2019 naik sebesar 8.03\% yang tadinya 1.653.514,54 menjadi 1.791.693,26 serta penetapan diskresi upah bagi kabupaten/kota yang belum mencapai nilai KHL (citrust.id, 2018).

Ketua Federasi Serikat Buruh Garmen, Tekstil, Kulit dan Sentra Industri Kabupaten Majalengka berharap agar Pemerintah, Dewan Pengupahan, Asosiasi Pengusaha Indonesia (APINDO), Perusahaan, Serikat Pekerja dan pihak-pihak lain yang terlibat dalam penyusunan rekomendasi nilai UMK dapat bersinergi dalam mengawal penerapan UMK di perusahaan yang ada di Kabupaten Majalengka sehingga dapat tercapainya tujuan penetapan nilai UMK yang pada hakikatnya hanya untuk pekerja lajang dan masa kerjanya di bawah satu tahun, sedangkan buruh yang masa kerjanya lebih dari satu tahun mengharapkan pemerintah untuk mendorong dan memberikan pemahaman kepada pengusaha untuk menerapkan struktur skala upah sesuai dengan pasal 14 PP No. 78 tahun 2015 yaitu "struktur skala upah sebagaimana dimaksud pasal 12 wajib disusun oleh pengusaha dengan memperhatikan golongan, jabatan, masa kerja, pendidikan, dan kompetensi". Selain itu, Cecep Nugraha Jaelani selaku sekretaris organisasi tersebut mengajak kepada semua buruh di Majalengka untuk memperhatikan Kesehatan dan Keselamatan Kerja (K3) serta bekerja sesuai dengan Standar Operasional Prosedur (SOP) perusahaan masing-masing agar tercapainya standar produksi yang telah ditetapkan sehingga perusahaan dapat memberikan penghargaan supaya pekerja dapat lebih bersemangat lagi dalam bekerja (citrust.id, 2018).

\section{METODE PENELITIAN}

Metode yang di gunakan dalam penelitian ini adalah metode survey dengan metode analisis deskriptif dan verifikatif dengan pendekatan kuantitatif. Pengujian instrument penelitian dilakukan dengan menggunakan uji validitas, uji realibilitas dan uji normalitas data, sedangkan analisis data menggunakan Uji Regresi Linier 
Berganda dan koefisien determinasi. Pengujian hipotesis menggunakan uji t untuk uji parsial, dan uji f untuk uji simultan.

\section{Populasi dan Sampel}

Menurut Sugiyono $^{14)}$ (2016: 80) populasi adalah wilayah generalisasi yang terdiri atas obyek atau subyek yang mempunyai kualitas dan karakteristik tertentu yang ditetapkan oleh peneliti untuk dipelajari dan kemudian ditarik kesimpulannya.

Menurut Sugiyono $^{14)}$ (2014: 116) sampel adalah bagian dari jumlah dan karakteristik yang dimiliki oleh populasi tersebut. Teknik pengambilan sampel adalah teknik yang bertujuan untuk menentukan sampel yang akan digunakan dalam penelitian (Sugiyono ${ }^{14)}$, 2016: 81). Teknik pengambilan sampel yang digunakan dalam penelitian ini adalah probability sampling dengan simple random sampling.

\section{HASIL DAN PEMBAHASAN}

\section{Pengaruh Keadilan Prosedural Partisipatif terhadap Kepuasan Kerja Karyawan pada Industri Tekstil Sandang dan Kulit di Kabupaten Majalengka}

Berdasarkan hasil perhitungan variabel keadilan prosedural partisipatif terhadap kepuasan kerja karyawan dengan menggunakan bantuan program SPSS 21 hasil uji $t$, variabel keadilan prosedural partisipatif memiliki thitung 3,347 $\geq t_{\text {tabel }} 1,658$ dengan nilai signifikansi 0,001 <0,05. Hal ini berarti Ha diterima dan Ho ditolak yang menunjukkan bahwa keadilan prosedural partisipatif berpengaruh signifikan terhadap kepuasan kerja karyawan, sehingga hipotesis pertama yang menyatakan bahwa diduga terdapat pengaruh keadilan prosedural partisipatif terhadap kepuasan kerja karyawan dapat dibuktikan kebenarannya.

Dapat disimpulkan bahwa keadilan prosedural partisipatif mempunyai pengaruh yang signifikan terhadap kepuasan kerja karyawan pada industri tekstil sandang dan kulit di Kabupaten Majalengka. Artinya keadilan prosedural partisipatif dapat mendorong peningkatan kepuasan kerja karyawan industri tekstil sandang dan kulit di Kabupaten Majalengka. Hasil penelitian ini sesuai dengan penelitian yang telah dilakukan oleh Asep Qustolani2) (2015) yang menyatakan bahwa keadilan prosedural partisipatif berpengaruh positif dan signifikan terhadap kepuasan kerja karyawan.

Hasil penelitian ini sesuai dengan teori bahwa keadilan prosedural partisipatif adalah penilaian yang mengacu pada kewajaran proses bagaimana keputusan diambil disertai dengan peran serta dari karyawan (Asep Qustolani3), 2018). Adil secara prosedural terjadi jika seorang karyawan merasa diperlakukan atau mengalami proses kerja yang sesuai dengan ketentuan yang ada (Asep Qustolani'3), 2018). Artinya apabila keadilan prosedural dan partisipasi karyawan sudah dijalankan dengan sesuai di suatu perusahaan, maka karyawan akan merasa 
senang karena hak-haknya terpenuhi dan keberadaannya dihargai di perusahaan tersebut sehingga karyawan akan merasa puas. Peran partisipasi manajer pusat pertanggungjawaban (MPP) sangat erat hubungannya dengan keadilan prosedural. Karena seluruh MPP jika telah berperan melaksanakan tugas dalam tanggungjawab yang diembannya secara efektif dan efisien, maka akan terlaksanalah prosedur secara adil dan akan meningkatkan kinerja manajerial yang berdampak kepada kepuasan kerja (Asep Qustolani'3), 2018).

\section{Pengaruh Internal Locus of Control terhadap Kepuasan Kerja Karyawan pada Industri Tekstil Sandang dan Kulit di Kabupaten Majalengka}

Berdasarkan hasil perhitungan variabel internal locus of control terhadap kepuasan kerja karyawan dengan menggunakan bantuan program SPSS 21 hasil uji $t$, variabel internal locus of control memiliki thitung 5,162 $\geq$ tabel 1,658 dengan nilai signifikansi 0,000 $<0,05$. Hal ini berarti Ha diterima dan Ho ditolak yang menunjukkan bahwa internal locus of control berpengaruh signifikan terhadap kepuasan kerja karyawan, sehingga hipotesis kedua yang menyatakan bahwa diduga terdapat pengaruh internal locus of control terhadap kepuasan kerja karyawan dapat dibuktikan kebenarannya.

Dapat disimpulkan bahwa internal locus of control mempunyai pengaruh yang signifikan terhadap kepuasan kerja karyawan pada industri tekstil sandang dan kulit di Kabupaten Majalengka. Artinya internal locus of control dapat mendorong peningkatan kepuasan kerja karyawan industri tekstil sandang dan kulit di Kabupaten Majalengka. Hasil penelitian ini sesuai dengan penelitian yang telah dilakukan oleh Kuni Zakiyah (2017) yang menyatakan bahwa internal locus of control berpengaruh positif dan signifikan terhadap kepuasan kerja karyawan.

Hasil dari penelitian tersebut sesuai dengan teori Rotter ${ }^{12)}$ (1966) yang menyatakan bahwa individu dengan internal locus of control meyakini suatu kejadian berupa kegagalan-kegagalan atau keberhasilan-keberhasilannya itu merupakan hasil dari tindakan dan perilakunya sendiri atau kemampuan mereka. Seorang internal locus of control percaya bahwa dia dapat merubah lingkungan yang dirasa tidak memuaskan (Cooper dan Payne, 1991). Dengan demikian, dapat dikatakan bahwa apabila seseorang memiliki pusat kendali yang baik maka akan memperoleh output yang diharapkan, sehingga apabila internal locus of control seorang karyawan baik maka dapat meningkatkan kepuasan kerjanya juga. Apabila kepuasan kerja yang dirasakan rendah, maka dia dapat mengubah hal tersebut dengan cara memperbaiki internal locus of control yang ada pada dirinya. Individu dengan internal locus of control yakin bahwa mereka merupakan pemegang kendali atas apapun yang terjadi pada diri mereka, individu yang yakin bahwa pemegang kendali atas apapun yang terjadi pada diri mereka adalah yang berasal dari kemampuan (ability), usaha (effort) dan keahlian (skill) sendiri (Permatasari dan Andari Putri, 2013), sehingga apabila dia dapat memegang kendali dirinya secara teratur dan baik saat melakukan suatu pekerjaan, maka akan berdampak pada kepuasan kerja yang dia rasakan. 
Pengaruh Keadilan Prosedural Partisipatif dan Internal Locus of Control terhadap Kepuasan Kerja Karyawan pada Industri Tekstil Sandang dan Kulit di Kabupaten Majalengka

Berdasarkan hasil perhitungan variabel keadilan prosedural partisipatif dan internal locus of control terhadap kepuasan kerja karyawan dengan menggunakan bantuan program SPSS 21 hasil uji F diperoleh $F_{\text {tabel }}$ sebesar 3,08. Karena $F_{\text {hitung } 20,277 \geq F_{\text {tabel }}}$ 3,08 dengan nilai signifikansi 0,000 <0,05. Hal ini berarti Ha diterima dan Ho ditolak yang menunjukkan bahwa keadilan prosedural partisipatif dan internal locus of control berpengaruh signifikan terhadap kepuasan kerja karyawan, sehingga hipotesis ketiga yang menyatakan bahwa diduga terdapat pengaruh keadilan prosedural partisipatif dan internal locus of control terhadap kepuasan kerja karyawan dapat dibuktikan kebenarannya.

Dapat disimpulkan bahwa keadilan prosedural partisipatif dan internal locus of control mempunyai pengaruh yang signifikan terhadap kepuasan kerja karyawan pada industri tekstil sandang dan kulit di Kabupaten Majalengka. Artinya keadilan prosedural partisipatif dan internal locus of control dapat mendorong peningkatan kepuasan kerja karyawan pada industri tekstil sandang dan kulit di Kabupaten Majalengka. Hasil penelitian ini sesuai dengan penelitian yang telah dilakukan oleh Gusmardi, Hia, dan Saputra ${ }^{8)}$ (2017) yang menyatakan bahwa keadilan prosedural dan internal locus of control berpengaruh positif dan signifikan terhadap kepuasan kerja karyawan.

Hasil penelitian ini sesuai dengan teori yang menyatakan bahwa apabila keadilan prosedural dan partisipasi karyawan sudah dijalankan dengan sesuai di suatu perusahaan, maka karyawan akan merasa senang karena hak-haknya terpenuhi dan keberadaannya dihargai di perusahaan tersebut sehingga karyawan akan merasa puas (Asep Qustolani ${ }^{3)}$, 2018). Peran partisipasi manajer pusat pertanggungjawaban (MPP) sangat erat hubungannya dengan keadilan prosedural. Karena seluruh MPP jika telah berperan melaksanakan tugas dalam tanggungjawab yang diembannya secara efektif dan efisien, maka akan terlaksanalah prosedur secara adil dan akan meningkatkan kinerja manajerial yang berdampak kepada kepuasan kerja (Asep Qustolani ${ }^{3)}$, 2018). Dan seorang internal locus of control percaya bahwa dia dapat merubah lingkungan yang dirasa tidak memuaskan (Cooper dan Payne ${ }^{4)}$, 1991). Dengan demikian, dapat dikatakan bahwa apabila seseorang memiliki pusat kendali yang baik maka akan memperoleh output yang diharapkan, sehingga apabila internal locus of control seorang karyawan baik maka dapat meningkatkan kepuasan kerjanya juga. Dari teori-teori tersebut dapat disimpulkan bahwa keadilan prosedural partisipatif dan internal locus of control dapat mendorong peningkatan kepuasan kerja karyawan.

Berikut ini adalah besarnya pengaruh variabel keadilan prosedural partisipatif terhadap kepuasan kerja karyawan, besarnya pengaruh internal locus of control terhadap kepuasan kerja karyawan, serta besarnya pengaruh keadilan 
prosedural partisipatif dan internal locus of control terhadap kepuasan kerja karyawan.

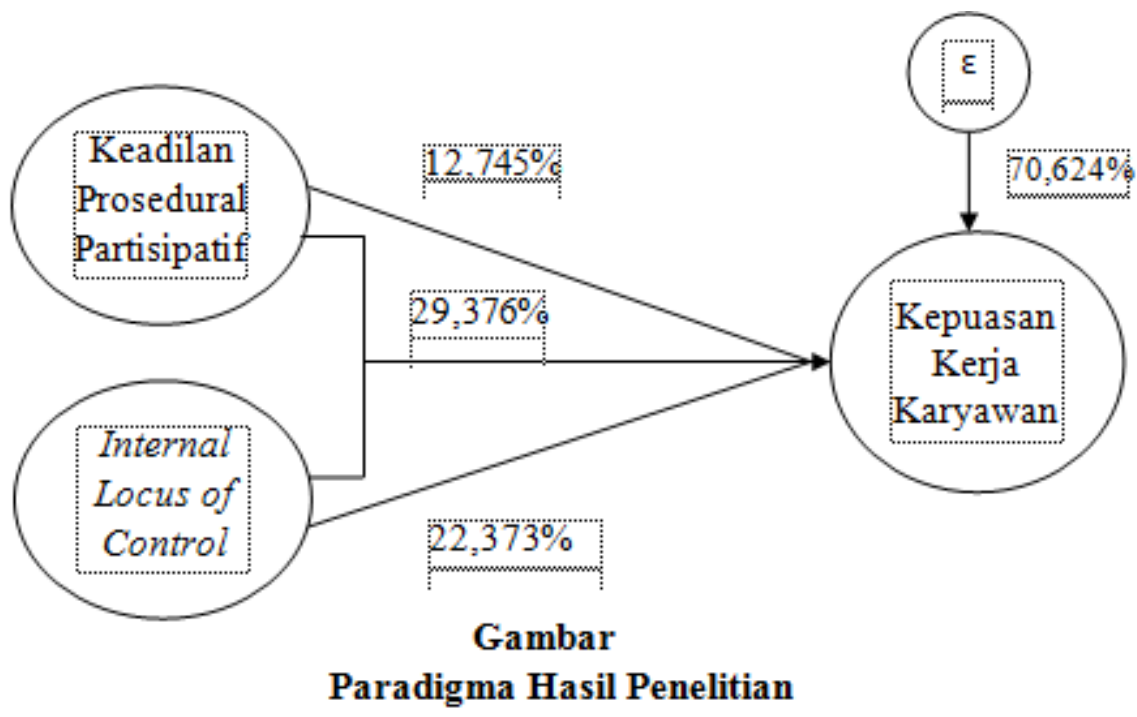

KESIMPULAN DAN SARAN

\section{Kesimpulan}

Berdasarkan hasil penelitian dan analisis data yang telah dilakukan pada karyawan industri tekstil sandang dan kulit di Kabupaten Majalengka mengenai variabel keadilan prosedural partisipatif dan internal locus of control terhadap kepuasan kerja karyawan, maka peneliti mengambil kesimpulan sebagai berikut :

1. Keadilan prosedural partisipatif berpengaruh positif dan signifikan terhadap kepuasan kerja karyawan pada industri tekstil sandang dan kulit di Kabupaten Majalengka. Artinya semakin tinggi keadilan prosedural partisipatif maka semakin tinggi pula tingkat kepuasan kerja karyawannya. Begitupula sebaliknya, semakin rendah keadilan prosedural partisipatif maka semakin rendah pula tingkat kepuasan kerja yang dirasakan oleh karyawan. Berdasarkan pernyataan tersebut, dapat dikatakan bahwa terdapat pengaruh keadilan prosedural partisipatif terhadap kepuasan kerja karyawan pada industri tekstil sandang dan kulit di Kabupaten Majalengka.

2. Internal locus of control berpengaruh positif dan signifikan terhadap kepuasan kerja karyawan pada industri tekstil sandang dan kulit di Kabupaten Majalengka. Artinya semakin baik internal locus of control maka semakin tinggi tingkat kepuasan kerja karyawannya. Begitupula sebaliknya, semakin buruk internal locus of control maka semakin rendah tingkat kepuasan kerja yang dirasakan oleh karyawan. Berdasarkan pernyataan tersebut, dapat dikatakan 
bahwa terdapat pengaruh internal locus of control terhadap kepuasan kerja karyawan pada industri tekstil sandang dan kulit di Kabupaten Majalengka.

3. Keadilan prosedural partisipatif dan internal locus of control berpengaruh positif dan signifikan terhadap kepuasan kerja karyawan pada industri tekstil sandang dan kulit di Kabupaten Majalengka. Artinya semakin tinggi keadilan prosedural partisipatif dan semakin baik internal locus of control, maka semakin tinggi pula tingkat kepuasan kerja yang dirasakan oleh karyawan. Begitupula sebaliknya, semakin rendah keadilan prosedural partisipatif dan semakin buruk internal locus of control maka semakin rendah pula tingkat kepuasan kerja yang dirasakan oleh karyawan. Berdasarkan pernyataan tersebut, dapat dikatakan bahwa terdapat pengaruh keadilan prosedural partisipatif dan internal locus of control terhadap kepuasan kerja karyawan pada industri tekstil sandang dan kulit di Kabupaten Majalengka.

\section{Saran}

Berdasarkan hasil penelitian dan pembahasan yang telah dilakukan, peneliti memberikan saran yang diharapkan dapat memberikan manfaat dan dapat dijadikan bahan pertimbangan bagi pihak-pihak yang berkepentingan, yaitu :

1. Pada variabel keadilan prosedural partisipatif, terdapat dua (2) nilai indikator dibawah rata-rata yaitu pada pernyataan tentang karyawan selalu diberi kesempatan untuk menyampaikan pendapat tentang gagasan atau ide yang dimiliki dan pada pernyataan tentang karyawan selalu hadir dan aktif dalam setiap acara rapat. Untuk pernyataan pertama, penulis menyarankan agar pimpinan lebih bersikap terbuka dalam setiap mengambil keputusan dan menerima pendapat-pendapat dari bawahannya. Untuk pernyataan kedua sekaligus sebagai skor terendah, penulis menyarankan kepada karyawan industri tekstil sandang dan kulit di Kabupaten Majalengka untuk menumbuhkan rasa peduli terhadap partisipasi yang ada dalam perusahaan. Selain itu, karyawan juga harus memahami arti penting dari sebuah peran dalam kegiatan rapat karena berkaitan dengan diskusi untuk bertukar pikiran sehingga akan menghasilkan informasi-informasi yang bermanfaat bagi mereka sendiri. Di lain pihak, pimpinan pada perusahaan-perusahaan yang bersangkutan harus memberikan arahan dan motivasi yang membangun kepada karyawan. Selain itu, pimpinan juga harus menegur dan memberikan sanksi yang tegas kepada karyawan yang malas dalam menghadiri kegiatan rapat.

2. Pada variabel internal locus of control, terdapat dua (2) nilai indikator dibawah rata-rata yaitu pada pernyataan tentang karyawan selalu berusaha untuk mampu menangani sebuah frustasi, dan pada pernyataan tentang karyawan selalu berpikir kritis untuk memperkirakan kemungkinan-kemungkinan yang terjadi di masa depan. Untuk pernyataan pertama, penulis menyarankan kepada pimpinan untuk lebih santai dalam mengatur bawahannya namun tetap 
harus serius, atau dalam kesempatan lain pimpinan bisa mengajak bawahannya untuk refreshing bersama-sama untuk meminimalisir kejenuhan akibat rutinitas pekerjaan. Untuk pernyataan kedua sekaligus sebagai skor terendah, penulis menyarankan kepada karyawan industri tekstil sandang dan kulit di Kabupaten Majalengka agar lebih berpikir maju perihal estimasi-estimasi yang terjadi di masa depan. Hal tersebut bisa dilakukan dengan dorongan-dorongan yang dilakukan oleh pimpinan di perusahaan masing-masing untuk senantiasa memberikan nasihat-nasihat atau memberikan informasi penting terkait masa lalu untuk mengestimasi dan memperbaiki keadaan yang terjadi di masa sekarang maupun masa yang akan datang.

3. Pada variabel kepuasan kerja karyawan, terdapat dua (2) nilai indikator dibawah rata-rata yaitu pada pernyataan tentang karyawan merasa senang dalam melaksanakan tugas pekerjaan setiap hari, dan pada pernyataan tentang gaji yang diterima cukup untuk kebutuhan sehari-hari. Untuk pernyataan pertama, penulis menyarankan kepada pimpinan untuk lebih bersikap friendship agar karyawan merasa betah saat bekerja dan memberikan motivasi yang membangun seperti pembagian reward atau bonus kepada karyawan yang telah menjalankan tugasnya dengan baik agar dapat meningkatkan semangat kerja karyawan itu sendiri. Untuk pernyataan kedua sekaligus sebagai skor terendah, penulis menyarankan kepada karyawan industri tekstil sandang dan kulit di Kabupaten Majalengka agar lebih banyak bersyukur dalam menjalani hidup ini. Gaji akan merasa cukup apabila kita benar-benar berbelanja sesuai dengan apa yang dibutuhkan, bukan menuruti setiap keinginan. Di lain pihak, pimpinan perusahaan-perusahaan yang bersangkutan harus memberikan gaji secara adil dan sesuai dengan jabatan pekerjaan yang diemban oleh karyawannya.

4. Bagi peneliti selanjutnya hendaknya melanjutkan penelitian ini dengan menambah variabel lain seperti produktivitas kerja, atau menggunakan variabel intervening agar berbeda dengan variabel yang digunakan dalam penelitian ini.

\section{DAFTAR PUSTAKA}

Anwar Prabu Mangkunegara. 2015. Manajemen Sumber Daya Manusia Perusahaan. PT Remaja Rosdakarya. Bandung.

Asep Qustolani. 2015. Pemodelan Keadilan Prosedural Partisipatif dalam Usaha Meningkatkan Kinerja Karyawan. Disertasi. Universitas Diponegoro. Semarang.

Asep Qustolani, Suharnomo, Lala Irviana, dan Imam Ghozali. 2018. The Modelling of Participative Procedural Justice to Improve Employee Job Satisfaction Using Structural Equation Modeling. International Journal of Civil Engineering and Technology 9(2): 883-897.

Cooper. C.L., and Payne. R., 1988. Causes, Coping and Consequences of stress at work. New York, Wiley. 
Dadang Sudirno dan L Suparto LM. 2017. Metode Penelitian Ekonomi E Bisnis Teori dan Aplikasi. FEB UNMA. Majalengka.

Edy Sutrisno. 2016. Manajemen Sumber Daya Manusia. Kencana. Jakarta.

Ghufron. (2010). Teori-teori Perkembangan. Bandung: Refika Aditama

Gusmardi, Hia, dan Saputra. 2017. Pengaruh Keadilan Distributif, Keadilan Prosedural, Keadilan Interaksional, dan Locus of Control terhadap Kepuasan Kerja Karyawan. Jurnal Manajemen Sumber Daya Manusia: 1-10.

Hasibuan, Malayu S.P. 2016. Manajemen Sumber Daya Manusia. PT Bumi Aksara. Jakarta.

Rotter, J.B. (1966) The Social Learning Theory of Julian B. Rotter.

Rena Nurjanah. 2018. Pengaruh Internal Locus of Control dan Kecerdasan Adversitas terhadap Kinerja Karyawan. Skripsi. Universitas Majalengka. Majalengka.

Sondang P. Siagian. 2010. Manajemen Sumber Daya Manusia, Bumi Aksara, Jakarta.

Sukestiyarno. 2014. Statistika Dasar. Yogyakarta: Universitas Negeri Semarang. Andi Offset.

Sugiyono. 2016. Metode Penelitian Kuantitatif, Kualitatif, dan RED. PT Alfabeta. Bandung. 